8. Лившиц В.Н. Гений - он гений, доступа: https://knigogid.ru/books/104607потому, что гений [Электронный ресурс]. - bumazhnyy-rubl

Режим доступа: http://www.cemi.rssi.ru/news/science/Lifshit.pdf

9. План Балчуна: вместо крюковских вагонов протащить польские [Электронный ресурс]. - Режим доступа: http://vlasti.net/news/257551

10. Обережно! Реформа розпочинається [Електронний ресурс]. Режим доступу: http://www.epravda.com.ua/columns/2012/02 /27/317098/

11. Шарапов С.Ф. Бумажный рубль [Электронный ресурс]. - Режим
12. Струмилин С.Г. Избранные произведения. Т.1.Статистика и экономика. [Текст]/ С.Г. Струмилин, М.: Изд-во Академии наук СССР, 1963. - 488 c.

13. Статистический ежегодник за 1914 г. под ред. В.И. Шарого.- СПб.: Совет Съездов представителей промышленности и торговли, 1914. XXXIII, 849 c.

14. Кокорев В.А. Экономические провалы [Электронный ресурс]. - Режим доступа: http: royallib.ru

\title{
СИСТЕМНО - ФЕНОМЕНОЛОГІЧНИЙ ПІДХІД ДО ФУНДАЦЇ̈ ПРОБЛЕМИ ІНТЕНЦЙНОГО КЕРУВАННЯ РУХОМ ЗАЛІЗНИЧНОГО ТРАНСПОРТУ В УМОВАХ ЗНАЧНОГО ЗРОСТАННЯ ШВИДКОСТІ ПОЇЗДІВ
}

\author{
Петрушов В. М., д.філос.н., професор (УкрДУЗТ)
}

У статті автор звертається до проблеми пошуку нової форми здій-снення керування об'єктами $і$ прочесами на залізничному транспорті в умовах значного зростання швидкості поїздів. Пошук здійснюється на філософському підгрунті феноменології Е.Гуссерля та фундаментальної онтологї М.Гайдеггера.

Обгрунтовано методологічний зв'язок між поняттями інтенціональності та керування, що створює передумови для виявлення формально-логічних відномень між об'єктом та суб'єктом керування.

Показано, щзо феномен інтенційного керування відкриває шлях до розробки нових когнітивних технологій, здатних забезпечити прийняття оптимальних рімень персоналом структурних підрозділів залізниць у складних умовах зростання інтенсивності руху поїдів.

Ключові слова: інтенціональність, інтенційне керування, оптимальне рішення, семантичний зв'язок, феноменальне тіло, мислення, свідомість, виконання інтенції. 


\title{
СИСТЕМНО - ФЕНОМЕНОЛОГИЧЕСКИЙ ПОДХОД К ОБОСНОВАНИЮ ПРОБЛЕМЫ ИНТЕНЦИОНАЛЬНОГО УПРАВЛЕНИЯ ДВИЖЕНИЕМ ЖЕЛЕЗНОДОРОЖНОГО ТРАНСПОРТА В УСЛОВИЯХ ЗНАЧИТЕЛЬНОГО УВЕЛИЧЕНИЯ СКОРОСТИ ПОЕЗДОВ
}

\author{
Петрушов В.Н., о.филос.н., профессор (УкрГУЖТ)
}

В статье автор обращается к проблеме поиска новой формы осуществления управления объектами и процессами на железнодорожном транспорте в условиях значительного увеличения скорости поездов. Поиск ведется на философской основе феноменологии Э.Гуссерля и фундаментальной онтологии М.Хайдеггера.

Обоснована методологическая связь между понятиями интенциональности и управления,что создает предпосылки для установления формально-логических отнотений между объектом и субъектом управления.

Показано, что феномен интенционального управления открывает путь к разработке новых когнитивных технологий, способных обеспечить принятие оптимальных решений персоналом структурных подразделений железных дорог в сложных условиях роста интенсивности движения поездов.

Ключевые слова: интенциональность, интенциональное управление, оптимальное решение, семантическая связь, феноменальное тело, мышление, сознание, исполнение интенции.

\section{SYSTEM PHENOMENOLOGICAL APPROACH TO THE RATIONALE OF THE PROBLEM OF INTENTIONAL GOVERNANCE THE MOVEMENT OF RAILWAY TRANSPORT IN CONDITIONS OF SIGNIFICANT INCREASE OF TRAIN SPEED}

\author{
Petrushov V. N., Doctor of Philosophy, Professor (USURT)
}

In the article the author turns to the problem of searching for a new form of implementation Management of objects and processes on railway transport in conditions Significant increase in the speed of trains. The search is conducted on the philosopherThe basis of the phenomenology of E. Husserl and the fundamental ontology of M.Haydegger.

The methodological connection between the concepts of intentionality and management, which creates the prerequisites for establishing formal-logical relations between the object and the subject of management.

It is shown that the phenomenon of intentional management opens the way to the development of new cognitive technologies capable of ensuring acceptance optimal decisions by the personnel of structural subdivisions of iron Horn in difficult conditions of growth of intensity of movement of trains.

Keywords: intentionality, intentional management, optimal solution, a semantic connection, a phenomenal body, a mouse consciousness, the fulfillment of intention.

Постановка проблеми. системи керування у тих галузях, де Випереджуючий розвиток інформаційних інтенсивність виробничих процесів технологій вимагає створювати й адекватні перевищує ергатичні можливості людини, 
задіяної у них у якості оператора чи особи, яка приймає рішення. Наближається час, коли машино-людський інтелект досягне такого рівня інтегрованості, що людська свідомість стане безпосереднім інструментальним чинником у функціонуванні вже існуючих нейрокомп'ютерних інтерфейсів, поєднуючих розум людини 3 штучним інтелектом. Вирішуючи технічні проблеми на цьому шляху, дослідники майже не приділяють належної уваги до філософсько-методологічних питань взаємодії свідомості людини $з$ програмноапаратними засобами згаданих інтерфейсів. Проте при цьому виникає ціла низка особливостей саме методолгічного характеру, без врахування яких просування у напряму розробки іноваційних технологій стане проблематичним або ж взагалі неможливим.

Підвищення професійних вимог до персоналу, значне ускладнення умов фахово-виробничої діяльності, безумовне виконання засад безпеки руху поїдів обумовлюють нагальну потребу в принципово новому баченні розв'язання проблеми людського чинника на підгрунті сучасних інформаційних технологій, поєднуючи у собі некласичні принципи раціональності мислення людини та трансформаційно-ментальні можливості комп'ютерних систем, здатних відтворювати різні аспекти віртуальної реальності.

Перетікання поточних даних про стан об'єктів керування у відповідні фрагменти комп'ютерної моделі ситуації спостереження і необхідність зворотної інтерпретації модельованих показників (образів) вже в якості адекватного рішення принципово змінює самий зміст поняття його оптимальності через складний характер сприйняття віртуальної реальності суб'єктом діяльності (диспетчером, машиністом локомотива). Максимальне спрощення образів моделювання полегшує ïx сприйняття, але в той же час знижує адекватність відображення дійсної обстановки, що безумовно потребує нових концептуальних схем прийняття оптимальних рішень.

Ці проблемні питання досліджувались і продовжують досліджуватися за кордоном (у Франції, Німеччині, Японіiі) при створенні та експлуатації високошвидкісного залізничного транспорту. Досвід експлуатації швидкісних поїздів TGV, AGV (Франція), Transrapid, ICE (Німеччина), Shinkansen, ML (Японія) засвідчує постійну увагу 3 боку розробників та експлуатаційників до питань удосконалення систем керування рухом, у яких оптимальність рішень базується на втіленні концепції «швидкість - комфорт безпека». Ця концепція виходить 3 того, що критерій «швидкість / безпека» у своєму оптимальному співвідношенні тісно пов'язаний 3 високою динамікою зміни координат перебування поїзда на трасі руху: дійсне місцеположення потягу i прогнозоване (модельоване) майже збігаються у часі та просторі, що викликає потребу у диспетчера й у машиніста орієтуватися саме у віртуальній реальності, яка синтезує у собі дійсне і можливе.

Така подвійність образного відображення ситуації керування потребує від персоналу й відповідної здатності до «подвійної рефлексії» інформації, що надходить від бортових та центральних комп'ютерів.

Таким чином, проблема прийняття оптимальних рішень персоналом швидкісних залізниць методологічно у своєму розв'язанні пов'язана 3 філософськими аспектами встановлення змістовно-формального співвідношення між дійсним та можливим (в контексті оцінки віртуальної реальності), здійснення «подвійної рефлексії» інформаційних образів 3 елементами поточнопрогнозованих характеристик швидкоплинної обстановки, в якій перебуває потяг, а також врахування раціональних та контрраціональних чинників прийняття рішень.

Вісник економіки транспорту і промисловості № 58, 2017 
Отже задача подолання деяких філософських й методологічних труднощів у сфері пошуку нових форм керування у відповідності до перспективних засобів інформаційних технологій стоїть досить актуально.

Аналіз останніх досліджень та публікацій. Про те, що свідомість людини може мати вирішальне значення для інструменталізації систем керування через конституювання інтенціональності як «робочого засобу», що взаємодіє з іншими елементами систем, вперше висловив думку Д.Деннет [1]. Великий вплив на розуміння активно-дієвої природи ментальних станів свідомості людини мала точка зору Т.Нагеля, яка полягає у тому, що усі вони мають характеризуватися трьома ознаками:функціональними,

феноменологічними та фізіологічними [2]. Мотрошилова Н.В., досліджуючи інтенціональність у контексті гуссерлівських напрацювань, дійшла висновку, що існує методологічна можливість перейти від феноменологічної статики до феноменологічної динаміки, зробивши акцент на понятті «виконання інтенції». Таким чином, інтенція подається рухомою, здатною до самореалізації [3]. Узагальнюючі підстави для розгляду свідомості й інтенціональності як особливих «конструктивних чинників» у розумінні поведінки людини створені авторами енактивізму (Ф.Варела, Е.Томпсон, А.Ное, У.Матурана та інші) [4]. Особливе значення для пошуку сучасних методологічних платформ створення іноваційних інформаційних технологій мають наробки Редько В.Н., який розкрив конструктивні можливості феноменології Е.Гуссерля і фундаментальної онтології М.Гайдеггера стосовно прагматики здійснення перспективних проектів [5].

Виходячи 3 цих та інших досліджень, автор даного допису мав на меті наукової статті здійснити філософсько-методологічний пошук нової форми керування швидкісним рухом залізничних потягів, враховуючи попередні результати вже раніше виконаних наробок у цьому напрямку.

Виклад основного матеріалу. Сучасний стан розвитку залізничного транспорту дозволяє встановити його домінуючі тренди - це, перш за все, суттєве зростання швидкості потягів, а також, як наслідок цього чинника, збільшення інтенсивності руху на залізницях [6].

Звичайно, що ці показники зумовлені економічними вимогами, як то: великими об'ємами різноманітних вантажів для транзитних перевезень, посиленням транскордонних зв'язків між країнами в умовах глобалізації світової економіки, а також значними пасажиропотоками, вимагаючими сучасного обслуговування 3 відповідним рівнем комфорту та безпеки. Вочевидь, що логістичний простір керування рухом залізничного транспорту стає багатовимірним зі складною топологією та динамікою змін системної організації функціонування структурних підрозділів залізниць. В таких умовах найбільш чутливим питанням ефективного керування об'єктами та процесами на залізничному транспорті $€$ прийняття оптимальних рішень керівниками усих ланок взаємодії у загальній системі транспортної інфраструктури. Саме цій проблемі була присвячена науково дослідна робота [7], де вперше були обгрунтовані філософські та науково методологічні теоретичні засади ii розв'язання. Однією 3 особливостей зазначеного дослідження рішення як такого, притаманного людині (особі, що приймає рішення - ОПР), $є$ те, що воно 3 онтологічної точки зору виявляе амбівалентні модуси - одночасно постає і як феномен, і як екзистенція [8]. При цьому слід зазначити, що така обставина розгляду подвійної сутності рішення кардинально впливає й на характер процесів керування, відкриваючи нові аспекти їх організації та форми практичного втілення, бо вони теж стають феноменологічно-екзистенційними механізмами мислення ОПР [9].

Вісник економіки транспорту і промисловості № 58, 2017 
Отже виникає нагальна потреба мати як феноменологічне, так i екзистенційне уявлення про онтологічні особливості керування 3 «подвійною рефлексією», тобто керування, яке вимагає від ОПР здатності до перекомутації своєї уваги на різних напрямах (інтенціях) рефлексії в залежності від умов прийняття рішень (поточних обставин діяльності). I робити це треба у ергономічному середовищі, насиченому складними засобами сучасних інформаційних технологій, тим самим, стаючи складовою машино-людського інтелекту. У такому разі дослідженню підлягає семантичний зв'язок між категоріями інтенціональності й керування. Інакше питання можна поставити так: яким чином виникає семантичнй перетин значень інтенціональності та керування? Для подальших міркувань зазначимо, що керування як форма взаємодії різних об'єктів і суб'єктів завжди спрямоване на щось (або когось) і є актом (процесом), який виконується у відповідь на деякий вплив внутрішнього чи зовнішнього характеру для системи, що задіяна у цьому процесі. Таким чином, керування у самому загальному вигляді вже несе на собі відбиток інтенціональності.

У феноменології інтенціональність тлумачиться як невід'ємна, іманентна властивість свідомості, але «чистої» свідомості - трансцендентальної, винесеної за межі емпіричних обставин іiі існування [10].

Д.Деннет, як і деякі інші філософи, поширює межі інтерпретації інтенціональності, вбачаючи в ній своєрідну дослідницьку установку (вмотивованість), яка надає мотивацію до пояснення поведінки інтенціональної системи [1]. Така епістемологічна ситуація ускладнює розкриття сутності інтенційного керування (IК).

3 огляду на те, що ми здійснюємо пошук значення поняття IК як «технічне розкриття» поки ще невідомого аспекту керування, замаскованого суто прагматичними чинниками (ефективністю, здійсненням, досяжністю мети й таке інше), то варто звернутися до міркувань М.Гайдеггера 3 цього приводу: «Технічне розкриття таємничого відкриває перед самим собою (актом розкриття, авт.) свої власні, складно переплетені процеси тим, що керує ними. Керування, 3 свого боку, намагається забезпечити саме себе (тобто, здатне до самовідтворення, авт.)» [11]. Але ж «складно переплетені процеси» й забезпечують свою узгодженість, цілеспрямованість тим, що над ними панує інтенціональність, яка покликана актуалізувати дію (акт, процес) для виконання певної задачі, тобто керування стає інтенційним, телеологічним тоді, i тільки тоді, коли процеси у його основі здатні розкритися не тільки у дієвому значенні, але й у семантичному (інформаційному) плані, тим самим, відтворюючи ноемоноетичний аспект керування у якості базового регіону інтенціональності. Методологічно це означатиме вихід на деяку «задачу» інтенційного характеру, оскільки «...телос інтенціональності» залишається нездійсненим і навіть непізнаним у своєму домаганні, поступаючись іншим життєвим домаганням й потребам, але разом 3 тим свідомість не може винайти щось нове, коли вона не вийде за межі своєї інтенціональної імплікації, прориваючись до формулювання й визнання як деякої «задачі» [12]. Якщо ж дійсно таки «керування саме себе забезпечує» (налаштованістю на сталість, координацію, узгодженість параметрів й таке інше), то не тільки у частині самих процесів в їхній самоорганізації (синергетичності), але й і в наданні їм спільної інтенціональної спрямованості. У ментальній сфері для свідомості людини керування як вид діяльності сприймається характерною «задачею», яка виявляє саморозкриття феномену інтенціональності, тобто постає «задачею ІК». А щоб вона виникла не просто як будь-яке керування, а саме як інтенційне, свідомість повинна вийти «за

Вісник економіки транспорту і промисловості № 58, 2017 
межі своєї інтенціональної імплікації», перетинаючи межу власного буття (гайдеггерівського Dasein) й стати не тільки конституюючою свідомістю, але й свідомістю керуючою, яка досягає своєї мети, свій телос як $\delta \varepsilon \alpha \tau \varepsilon \lambda \varepsilon \varepsilon v \tau \alpha 1 \alpha$ (кінцеву ідею). Тут поняття «імплікація» слід сприймати у буквальному перекладі $з$ лат. implicatio - сплетіння, тісно пов'язати, що $\epsilon$ найбільш властивим для інтенціональності у якості іманентної модальності свідомості.

Таким чином, у контексті фундаментальної онтології Гайдеггера онтичне значення IК розкривається в принципово нових можливостях людини як у організації іiі мислення завдяки інтенційної координації процесів його забезпечення (уваги, сприйняття, уяви, атрибуції, антиципації), так і в здібностях взаємодіяти 3 предметами зовнішнього світу, зміщуючи діяльнісні акценти у телеологічному просторі керування, що дозволяє розглядати сутнісні аспекти IК на методологічних засадах кібернетики другого порядку і енактивізму $[4,13]$.

Тепер роздивимося дві версії експлікації IК на епістемологічному тлі вже відомих підходів до інтерпретації інтенціональності у якості ментального чинника, який регулює не тільки рівні й стани аперцептивних механізмів психіки суб'єкта керування, але й саму встановчомотиваційну його позицію відносно рівня складності здійснюваної ним діяльності.

Перша версія - класично феноменологічна у дусі теорії інтенціональності, створеної ще самим Е.Гуссерлем [14]. Якщо функціонально інтенціональність визначається як ментальний тип існування (тут вона виступає у якості предиката свідомості «бути свідомістю чогось» або ж «бути усвідомленим»),то структурно вона розшаровується на ноезіс (поле смислових конституюючих різноманіть) і ноему (поле смислових єдностей).Сама ж свідомість постає як «функціонально поєднуюче різноманіття i, водночас 3 тим, як конституююча єдність» (по Гуссерлю). Цю вже загальновизнану версію можна актуалізувати, якщо звернутися до сучасної парадигми трансверсального розуму. Виявляється, що гуссерлівське тлумачення свідомості збігається 3 ознаками трансверсальності розуму:свідомість сполучає протилежності - ноему (єдність) і ноезіс (різноманіття), а також здійснює між ними інтенціональні переходи у різних семантичних формах - «думка / образ / концепт». У підсумку конфігуруєтся семантичний простір 3 топологією «інтенціональної мережі» (Дж.Сьорл), подібний ризомі, що слугує концептом для моделі трансверсального розуму.

Виходячи $з$ усього вище наведеного, можна стверджувати, що потік свідомості принципово керований особистісним носієм свого Я (дух це чи воля або ж сила переконання - окрім нас самих про це ніхто не скаже!) шляхом звуження або розширення смислового поля. Іншими словами, перебудовуючи структуру інтенціональності таким чином, що свідомості відкривається горизонт бачення предмета чи явища у їхній смисловій «чистій іманентності»,у їхній«сутнісній експліцитності»,ми, тим самим, долаємо спонтанність свідомості, упорядковуючи думки та образи у відповідності до ракурсу сприйняття під кутом зору прийнятої установки на оточуючий світ, яка сама по собі динамічна і реактуалізується разом 3 інтенціональністю: «Для феноменологічної установки, як i для будь-якої іншої установки професійного інтересу всередині загального особистого часу, притаманна зміна актуалізації й деактуалізації; ця установка може «вмикатися і вимикатися» [15].

Отже, керуючи інтенціональністю, можна здійснювати процес реактуалізації установки мислення, що вельми близько до поняття ментального самокерування, яке розгортається у просторі й часі рекурсивно і сукцесивно, інкорпоруючись в загальний механізм темпорального аутопоезісу.

Друга версія, феноменальна, вибудована на теорії Мерло-Понті про

Вісник економіки транспорту і промисловості № 58, 2017 
феноменальне тіло[16]. Феноменальне тіло - це сфера інтенційно-діючої суб'єктивності, яка постає у вигляді духовно-тілесного організму як синергетична єдність унікальних утворень (мізок у сукупності з нервовою системою), нерозкладних цілісностей (психосоматичні структури, структури свідомості, їхні модальності), чуттєво-смислових ядер ( перцептивний апарат і кінестезичні механізми). Людина у нормі свого існування прагне так організувати (спрямувати)свою життєдіяльність, щоб можливості iï феноменального тіла були приведені у відповідність до цілей й задач життєвої програми, яка 3 часом також трансформується у частину феноменального тіла і як генетичний код i як інтенційно - керуючий чинник на усих рівнях особистісного становлення. Суб'єкт відкриває у собі потенційні можливості самооцінки, самоконтролю, самореалізації, самокерування i в найбільш загальному плані - самоорганізації. Синергетичні ефекти охоплюють й пронизують усе феноменальне тіло людини. Проте, так чи інакше, усі вони підпорядковані фундаментальному закону життя - закону збереження (виживання) на індивідуальному, родовому й видовому рівнях. Мовою синергетики це можна подати так, що феноменальне тіло постійно перебуває у сфері тяжіння направленого аттрактора в системі координатекзистенціалів - координат існування у життєвому світі, у його «фазовому просторі». Цей аттрактор виконує роль стабілізуючого чинника, який поєднує усі вище згадані «само - » у сталу траєкторію цілеспрямованості особистості. Вочевидь, що така модель замикання феноменального тіла на сталі структури життєвого світу припускає наявність розвиненої інструментальної системи комунікації, в якій усі аспекти самовираження людини знаходили б відповідний спосіб входження у глобальний «фазовий простір» як то інформаційний інтернетівський чи ментальний у єдності природи й розуму (ноосферний). Це означає, що інтенціональність стає «відчутнодотичною» в предметах діяльності, залучених у комунікативне поле, одним із сегментів якого може і повинне стати IК.

$$
\text { «Відчутна }
$$

дотичність»

інтенціональності й причетна до неї інструменталізація спостерігаються у сучасних засобах комунікації (комп'ютерах, телефонах мобільного зв'язку, навігаторах GPS i таке інше), оскільки тексти, образи, розмови, мапи місцевості, стаючи інтенціональними предметами діяльності (комунікації), втілюють у собі увесь спектр чуттєвогілетичних компонентів ноезіса структурного елемента інтенціональності.

Таким чином, феноменальна версія помітно підсилює i суттєво доповнює феноменологічну у плані розкриття інтенційної взаємодії суб'єкта 3 зовнішнім світом у формі інструментального зближення ментальної сфери i сфери предметної (речової), на перетині яких й повинне відбутися референціальне сполучення семантичних значень інтенціональності та керування у загальному визначенні ІК. При цьому, якщо залишитися у межах прийнятих уявлень про інтенціональність й керування, акцент уваги інтуїтивно все ж таки зміщується на бік інтенціональності. Тут «мислення функціонує як задання обрію для тлумачення буття 3 його модальностями» [17]. Слід нагадати, що у Гайдеггера інтенціональність «тут-буття» має екстатично-обрійний характер. Але як тільки виникає потреба у поясненні i уточненні нових категорій, скажімо, таких як IК, то межі традиційного розуміння інтенціональності та керування доведеться розширити за існуючі вже можливості мислення як рефлексії (з уявним обрієм), окреслюючи їх вже новими можливостями «мислення як рефлексії рефлексії» у гайдеггерівській контамінації «... прийомом, яким, мов би інструментом i знаряддям, тлумачиться побачене на обрії припускання буття» [17]. По суті тут

Вісник економіки транспорту і промисловості № 58, 2017 
йдеться про властивість мислення рекурсію, яка дозволяє 3 імпліцитно присутньої в керуванні інтенціональності винести ऑiі за «дужки рекурсії» у експліцитному вигляді, надавши ій гуссерлівського значення

«функціонуючої інтенціональності».

Розглядаючи IK як актуальну тезу здійснюваного тут феноменологічного аналізу, можна уявити процесуальність такого керування у вигляді «виконання інтенціі» (термін Гуссерля). Динаміка IК, як і мислення, пов'язаного з його здійсненням, теж повинна мати рекурсивний характер: «Усі обмірковані до цього часу модифікації уявлень доступні для утворення усе нових і нових ступенів так, що навіть й інтенціональності у ноезісі та ноемі поступово надбудовуються одна на одній або ж, скоріш за все, тільки одним єдиним способом вставляються одна в одну» [18].

У випадку IК рекурсивну динаміку мислення можна інтепретувати як багатоступе- неву феноменологічну редукцію 3 поступовим розгортанням ризомної структури типу «інтенційної мережі» Дж.Сьорла, наприклад, $\Sigma=\sigma$ ( $\sigma$ ( $\sigma \ldots(\sigma) \ldots)))$, де $\sigma-$ концепт обмірковування задачі керування, який поступово імплементується в споріднені концепти більш вищого рівня керованості об'єктом, відповідаючим за «виконання інтенції» $\Sigma$.

Задамося питанням, а чи здійснюване «виконання інтенції» практично? Попередні дослідження у [7] засвідчують, що так. На діючому макеті прилада був встановлений факт «виконання» мисленєвої команди, сформованої в уяві оператора таким чином, що головним чинником впливу на процес появи сигнала, засвідчуючого дійсність «виконання інтеції», була концентрація уваги саме на об'єкті спостереження (керування). Такий експеримент дозволяє поширити теорію IK як на навчання (тренування) операторів суто психологічними методами (в очікуванні ефекту підвищення нейропластичності мозку,що значно покращує здібності людини у прийнятті рішень) так й на розробку програмного забезпечення перспективних систем керування, у складі яких очікується появлення нейрокомп'ютерних інтерфейсів. Але ж звичайно, найбільш суттєвого ефекту від впровадження теорії і практики IК можно домогтися при комлексному (системному) підході до проектування й створення засобів ІІ 3 врахуванням людських i машинних можливостей у реалізації синергетично діючого функціоналу «виконання інтенції». Саме у цьому напрямку й будуть зосереджені подальші дослідження авторського колектива, залученого до вирішення проблеми розробки систем IК.

Підсумовуючи розгляд онтологічних аспектів постановки проблеми можливості існування IК як нової форми здійснення керівної діяльності людини у взаємодії 3 машинним інтелектом, зробимо такі Висновки:

1. Інтенціональність i керування, доповнюючі одне одного поняття, містять у собі не лише потенціал нового смислоутворення, але й відкривають перспективу розробки іноваційних когнітивних технологій на основі якісних трансформацій психічних можливостей людини і створення машинних інтерфейсів нового покоління (так званих нейрокомп'ютерних інтерфейсів).

2. Існує логіко - конструктивний зв'язок між динамікою IК та ризомнономадичними актами переходів у концептуальній моделі трансверсального розуму. Використання цього зв'язку стане у нагоді для побудови формально-логічних моделей (систем) IК.

3. Онтологічна платформа методологічної ескплікації ІК на основі фрагментів феноменології Е.Гуссерля та фундаментальної онтології М.Гайдеггера має значні можливості для розгортання теоретичних i практичних досліджень застосування IК у перспективних системах 
керування швидкісним рухом залізничного транспорту.

\section{ПЕРЕЛІК ВИКОРИСТАНИХ ДЖЕРЕЛ}

1. Деннет Д. Виды психики. Интенциональность: интенционально системный подход [Электронный pecypc] Д. Деннет. - Режим доступа: http://psylib.ukrweb.net/books/dennd01/txt0 2.htm . - Загл. с экрана.

2. Нагель Т. Мыслимость невозможного и проблема духа и тела / Нагель Т. //Вопросы философии. - 2001. № 8. - C. 101-112.

3. Мотрошилова Н.В. Интенциональность в «Логических исследованиях»Э.Гуссерля

Мотрошилова Н.В. // Вопросы философии. - 2000. - № 4. - С. 138-157.

4. Князева Е.Н. Энактивизм: концептуальный поворот в эпистемологии / Князева Е.Н. // Вопросы философии. - 2013. - № 10. - С. 91-104.

5. Редько Дескриптологические основания информационных технологий /Редько В.Н., Редько И.В. // Кибернетика и системный анализ. - 2007. - № 5. - С. 1228.

6. Журавель В. Аналіз досвіду використання високошвидкісних залізничних сполучень [Електронний ресурс] В. Журавель, І. Журавель // Міжнародний техніко-економічний журнал «Українська залізниця». - 2016. № $1 . \quad$ - Режим доступу: http://ukrrailways.com/statti/1892-analizdosvidu-vikoristannya-visokoshvidkisnikhzaliznichnikh-spoluchen.html . - Назва 3 екрану.

7. Звіт про науково-дослідну роботу «Філософське та науковометодологічне дослідження теоретичних засад прийняття оптимальних рішень персоналом структур та підрозділів залізничного транспорту в умовах значного зростання інтенсивності рухупоїздів». - 2009. - № держреєстрації 0109U001180 . - УкрДАЗТ.

8. Див. Звіт НДР. - С.20.

9. Див. Звіт НДР. - С.24-25.

10. Гуссерль Э. Картезианские медитации / Э. Гуссерль // - М.: Академический Проект, 2010. - 229с.

11. Хайдеггер М. Вопрос о технике / М.Хайдеггер // Время и бытие: статьи и выступления. - СПб.: Наука, 2007. C.314.

12. Блюменберг X. Жизненный мир и технизация с точки зрения феноменологии / X. Блюменберг // Вопросы философии. - 1993. - № 10. C.76.

13. Стюарт Амплби А. Кибернетика второго порядка: на пути к признанию / А. Стюарт Амплби // Университет им. Дж. Вашингтона, 1991. $187 \mathrm{c}$.

14. Гуссерль Э. Идеи к чистой феноменологии и феноменологической философии. Книга первая. / Э. Гуссерль // - М.: Академический Проект, 2009. $489 \mathrm{c}$.

15. Ямпольская А.В. Феноменологическая редукция как философская конверсия / A.В. Ямпольская // Вопросы философии . 2012 . - № 9. - С.157-168.

16. Соколова Л.Ю. Феноменологическая концепция М. Мерло-Понти [Электронный ресурс] Л.Ю. Соколова // Антропология. - Режим доступа:

http://anthropology.ru/texts/sokolova/kolesn _17.html . - Загл. с экрана.

17. Хайдеггер М. Тезис Канта о бытии / М.Хайдеггер // Время и бытие: статьи и выступления. - СПб.: Наука, 2007. - C.525.

18. Гуссерль Э. Идеи к чистой феноменологии и феноменологической философии. С.322. 